\title{
Doctrine of Novus Actus Interveniens Not Always a Defense: Analysis of a Case
}

\author{
Abhaykumar B Dheeraj ${ }^{1}$, Sandeep K Giri², Bedanta Sarma ${ }^{3}$
}

\begin{abstract}
Doctrine of novus actus interveniens (NAI) sometimes plays an important role as a tool of defense in medical negligence suits. It is a Latin phrase which means breakage of the causal chain at some point, relieving the initial wrongdoer. In medical negligence suits, the appearance of an external factor or event in the causal chain and the outcome is not directly related to the negligence of the doctor, but for the novel agent; the doctrine of NAI can be applied and the initial wrongdoer, i.e., the treating physician can be exempted. Autopsy of a similar type of case was performed in a tertiary care hospital in the State of Chhattisgarh. The autopsy findings identified a new factor in the form of dereliction in duty by another physician causing breakage of the chain in the current case described.

Keywords: Causal chain, Medical negligence, Novus actus interveniens.

Indian Journal of Critical Care Medicine (2020): 10.5005/jp-journals-10071-23634
\end{abstract}

\section{INTRODUCTION}

When a physician decides to give treatment to a patient, he/she owes a duty of reasonable degree of care and skill that shall be upheld throughout the treatment. ${ }^{1}$ If he fails to give such reasonable care, and negligence is established, doctor has to pay monetary compensation in civil cases, whereas in criminal cases imprisonment up to 2 years may be awarded according to the Indian law (Section 304-A IPC). ${ }^{2}$

In situations, where the doctor is negligent while delivering his services and there is harm to the patient, but the harm is not the direct result of the negligent act of the doctor/initial wrongdoer or the harm is the result of other novel factor, novus actus interveniens (NAI) comes into play as defense for initial wrongdoer.

Such a type of incidence was observed while conducting autopsy in a tertiary healthcare center in the State of Chhattisgarh, which revealed new undiagnosed findings, actually responsible for the cause of death.

\section{Case Description}

The 20-year-old male patient, victim of road traffic accident was brought to the trauma and emergency department of our center. He was brought in unconscious state with history of few episodes of vomiting and seizure. Initially, his glassgow coma scale (GCS) was E2VTM5, pupils bilaterally equally reactive to light 2 $\mathrm{mm}$. CT head showed contusion in right and left frontal region, subarachnoid hemorrhage $(\mathrm{SAH})$ in left Sylvian fissure with no midline shift or mass effect (Fig. 1A). Follow-up CT showed right fronto-parieto-temporal subdural hemorrhage (SDH) with diffuse cerebral edema causing midline shift and mass effect (Fig. 1B), and hence emergency surgery was planned by Neurosurgery department. Decompressive craniotomy with augmented duroplasty was performed with evacuation of SDH and frontal contusion and bone flap preserved per abdominally.

Postoperatively, patient was on ventilator and inotropic support. Postoperative CT showed resolving frontal bleed, small interhemispheric hygroma, and no tentorial infarct with improving

\footnotetext{
1,2Department of Forensic Medicine and Toxicology, All India Institute of Medical Sciences, Raipur, Chhattisgarh, India

${ }^{3}$ Department of Forensic Medicine and Toxicology, All India Institute of Medical Sciences, Mangalagiri, Andhra Pradesh, India

Corresponding Author: Sandeep K Giri, Department of Forensic Medicine and Toxicology, All India Institute of Medical Sciences, Raipur, Chhattisgarh, India, Phone: +91 7056424496, e-mail: drsandeep1912@ gmail.com
}

How to cite this article: Dheeraj AB, Giri SK, Sarma B. Doctrine of Novus Actus Interveniens Not Always a Defense: Analysis of a Case. Indian J Crit Care Med 2020;24(10):983-985.

Source of support: Nil

Conflict of interest: None

GCS (E4VTM6). Tracheostomy was performed on 3rd day and right subclavian central line was inserted on 4th day of postoperative period. His GCS started falling after putting central line. Moreover, the preoperative chest X-ray of the patient was normal (Fig. 1C), whereas the postcentral line chest $X$-ray showed hemogeneous opacity along the right lateral thoracic wall with blunting of right costophrenic angle, suggestive of right-sided pleural effusion (Fig. 1D). Clinical condition of the patient deteriorated and he died on 6th day after surgery.

\section{Autopsy Findings}

Deceased was an average built male. Body was pale on inspection. Body length $152 \mathrm{~cm}$. Rigor mortis and hypostasis in developing state. Findings noted:

- Tracheostomy. Needle puncture marks of varying sizes were noted over the right side supraclavicular area and right side of neck (Fig. 2A).

- Surgically sutured wound of decompression surgery. Missing bone fragment underneath it, over an area of $12 \times 9 \mathrm{~cm}$, with

() The Author(s). 2019 Open Access This article is distributed under the terms of the Creative Commons Attribution 4.0 International License (https://creativecommons. org/licenses/by-nc/4.0/), which permits unrestricted use, distribution, and non-commercial reproduction in any medium, provided you give appropriate credit to the original author(s) and the source, provide a link to the Creative Commons license, and indicate if changes were made. The Creative Commons Public Domain Dedication waiver (http://creativecommons.org/publicdomain/zero/1.0/) applies to the data made available in this article, unless otherwise stated. 

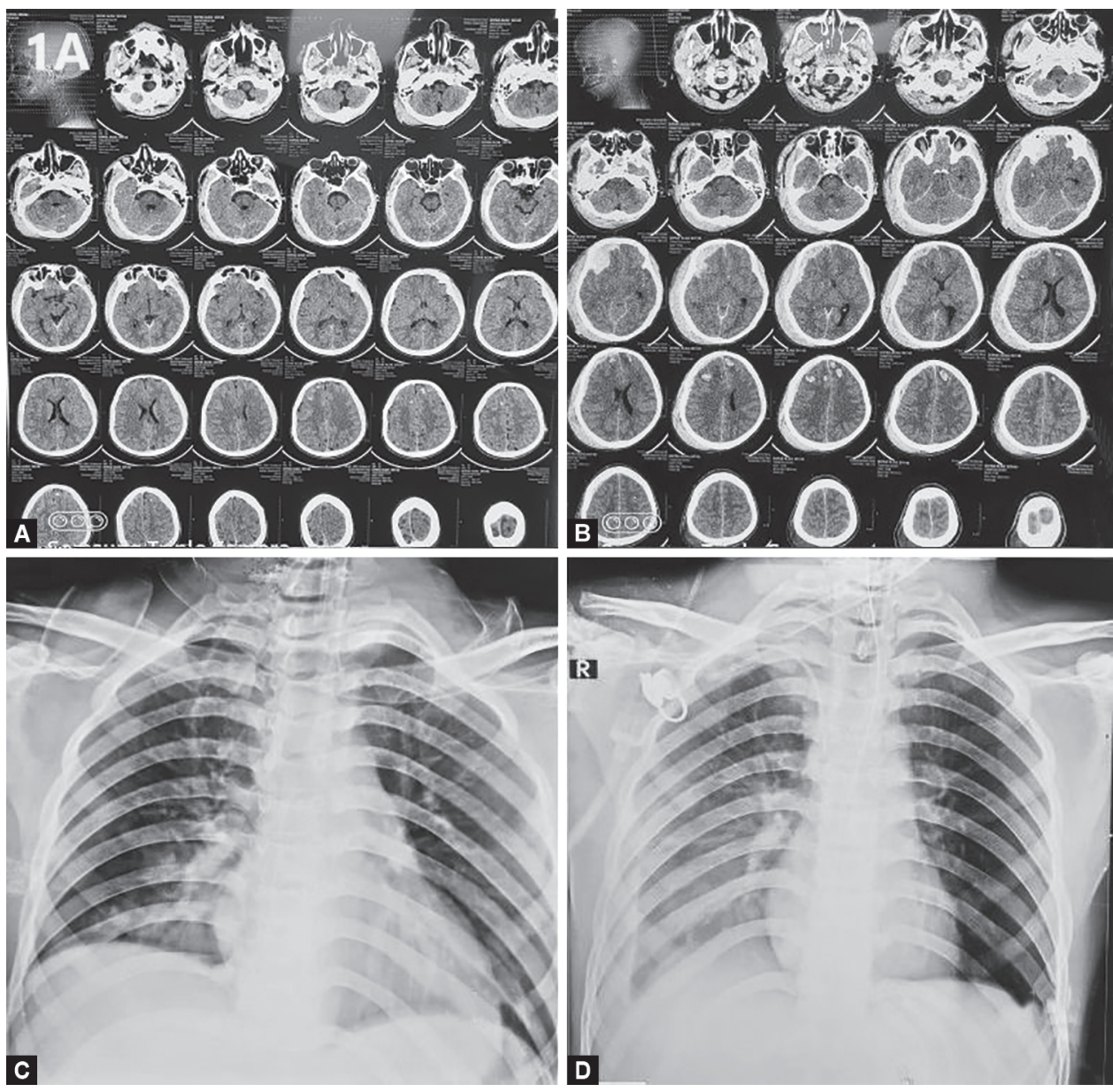

Figs 1 A to D: $(A, B)$ Preoperative CT Scans; (C) Chest radiograph before central line insertion; (D) Chest radiograph after central line insertion showing homogenous opacity with blunting of right costo-phrenic angle

evidence of duroplasty. Brain parenchyma showed focal SAH. No signs suggestive of massive cerebral edema was noted (wt. 1347 g) (Fig. 2B).

- Seven hundred grams of clotted blood found adherent to uppermost part of right pleura with $1,500 \mathrm{~cm}^{3}$ of fluid blood in cavity. Subcutaneous tissue and muscle around the clavicle and lower third of sternocleidomastoid muscle was ecchymosed. Right subclavian artery showed through and through puncture mark in proximal $1 \mathrm{~cm}$ course on the superior aspect, under the medial one-third of clavicle with ecchymosed surrounding deep tissue and clotted blood (Figs 2 C and D). Right lung, small in size (wt. $235 \mathrm{~g}$ ) and found shifted medially. Petechiae present over the surface of both lung (Lt.wt. $350 \mathrm{~g}$ ) and were pale.

Rest internal organs were pale. The bone flap as mentioned in the treatment record was not found anywhere in the body.

\section{Discussion}

Doctrine of NAl is a type of defense, which is mostly practiced in civil negligence cases. It is a Latin phrase which means there will be appearance of a new act or event in the causal chain between initial event, in a sequence and the result causing a break in the continuity of the same. ${ }^{3}$ Appearance of the intervening factor or the third party in the chain will give other result or worsens the appeared result. ${ }^{4}$ Hence, the independent and strong enough intervening act reduce or nullify the liability of the primary wrongdoer, thereby giving protection in the court of law. ${ }^{3}$
When a patient is getting treatment from a physician and there is negligence in his part, while discharging his duties, he can be sued on the basis of gravity of outcome and extent of negligence. However, in the course of the event, i.e., from initial negligence to the final outcome, if a new intervening factor appears in the form of negligence of patient or other medical personnel or by natural factors which breaks the causal chain, it can be a good defense for the physician, as he is not directly liable for the harm. As was popularized by Hart and Honore. ${ }^{5}$

In the present case, there is a dereliction of duty from the neurosurgeon as he did not preserve the skull bone piece as a part of the standard procedure. Bone was neither damaged nor deformed, presuming per se no contraindication for not preserving it. Hence, autopsy findings go against his favor proving his dereliction of duty.

On autopsy, other than focal SAH in the brain parenchyma (consistent with the postoperative NCCT findings), we did not notice any signs suggestive of massive cerebral edema (uncal/tentorial herniation or obliteration of gyri and sulci) that could have caused death. Hence, due to the presence of massive amount of clotted blood along with hemorrhage in the right pleural cavity (findings of postcentral line chest radiograph), we concluded the cause of death as hemorrhagic shock due to bleeding from punctured subclavian artery as a result of therapeutic cannulation associated with antecedent cause as resolving craniocerebral injuries.

Thus, in-charge anesthesiologist, who is supposed to have competency and skill for central line insertion, failed to 


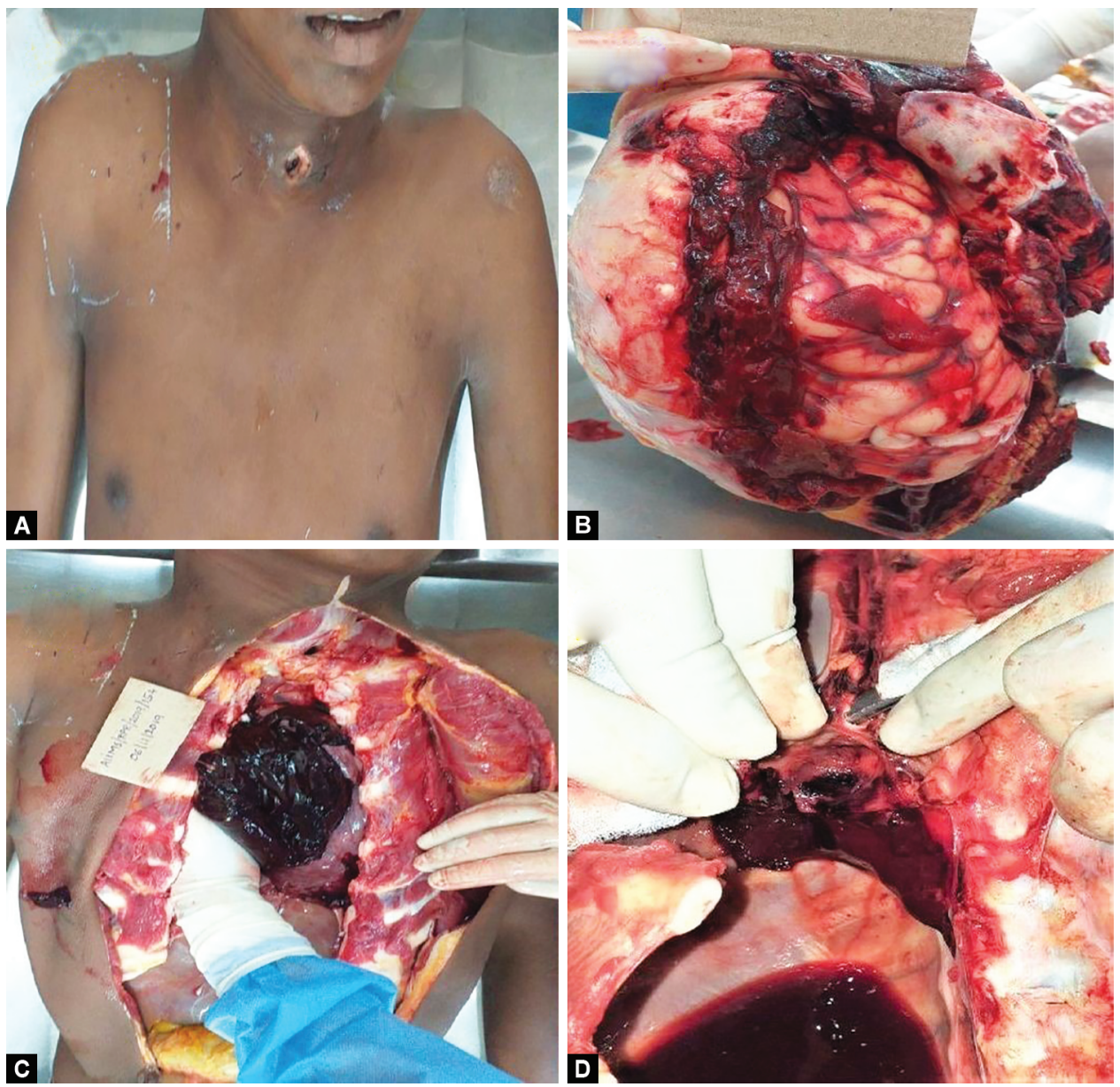

Figs 2A to D: (A) Showing needle puncture marks of central line, tracheostomy wound; (B) Missing bone flap right side with focal subarachnoid hemorrhage; (C) Removal of clotted blood of 700 grams; (D) Pin pointing of bleeding site on subclavian artery

show reasonable care in diagnosing the complication of the procedure. Despite radiological evidence of pleural effusion and deteriorating GCS after the procedure, no attempt was made to evaluate the clinical condition of the patient that led to fatal hemorrhagic shock. The clinical outcome in this case was modified due to the iatrogenic intervention, as the craniocerebral damage was resolving postoperatively. Hence, the principle of res-ipsa-loquitur can be directly linked to the therapeutic procedure performed by the anesthesiologist who is duty bound to take care of the patient.

Here, act of the anesthesiologist broke the causal chain in a case of craniocerebral damage and doctrine of NAl fits in which otherwise could have different clinical outcome.

\section{Conclusion}

It can be recommended that, every physician must take all the necessary actions to check the pertinence, proper functioning, and always rule out any foreseen complication in therapeutic procedures. If in this case alleged negligent suit would have been filed by the patient's relative, then the damages cause to the patient are directly linked to the care given by anesthesiologist rather than neurosurgeon.

Documentation of every aspect of treatment can be the only defense in alleged medical negligence suits.

\section{References}

1. Murthy KKSR. Medical negligence and the law. Indian J Med Ethics 2007;4(3):116-118. DOI: 10.20529/IJME.2007.046.

2. Reddy KSN. The Essentials of Forensic Medicine and Toxicology. 33rd ed., New-Delhi: Jaypee Brothers Med. Publisher; 2014. p. 40.

3. Gerner BA. Black's Law Dictionary. 8th ed., USA: Thomson Business; 2004.

4. Sofian A. Novus actus interveniens in the context of criminal law in Indonesia. Humaniora 2016;7(2):243-250. DOI: 10.21512/humaniora. v7i2.3527.

5. Hart HLA. Honore AM. Causation in the Law. 1st ed., Oxford: Oxford University Press; 1959. 